\title{
PROSES PENCOKELATAN JARINGAN ADIPOSA
}

\author{
Afifa Radhina \\ afifaradhina@gmail.com, Politeknik Kesehatan Hermina
}

\begin{abstract}
Obesity is a common, serious, and detrimental condition. In 2014, more than 1.9 billion adults were overweight. Obesity is associated with many diseases and the increase in obesity has become a major health problem. Obesity is caused by an imbalance between energy intake and energy consumption. There are two types of adipose tissue in the body with different functions, namely white adipose tissue and brown adipose tissue. White fat has a major function in storing energy and is increased in obesity, while brown fat produces heat (thermogenesis) and then increases energy consumption. Therefore, brown fat and the induction of brown fat-like properties in white fat, have been considered as targets in the fight against obesity. The purpose of this study was to determine the browning process of white adipose tissue. The research method used is the scientific search method. The results showed that beige adipocytes are brown adipocytes that appear in the precursor cells of white adipose tissue due to the presence of stimuli. Cream adipocytes, like brown adipocytes, are equipped with mitochondria containing uncoupling protein 1 (UCP1), which when activated controls ATP synthesis and stimulates respiratory chain activity. Several regulators such as PPAR, PGC-1 $\alpha$, and PRDM16 emerged as major actors in the process of beige adipocyte differentiation.
\end{abstract}

Keyword: Brown adipocyte, Beige adipocyte, Browning adipose tissue, UCP1

\begin{abstract}
Abstrak
Obesitas merupakan keadaan yang umum, serius, dan merugikan. Tahun 2014, lebih dari 1,9 milyar orang dewasa mengalami kelebihan berat badan. Obesitas berasosiasi dengan banyak penyakit dan peningkatan obesitas telah menjadi masalah kesehatan utama. Obesitas disebabkan oleh ketidakseimbangan antara energi yang masuk dan konsumsi energi. Jaringan adiposa dalam tubuh ada dua tipe yang fungsinya berbeda, yakni jaringan adiposa putih dan jaringan adiposa cokelat. Lemak putih berfungsi utama dalam menyimpan energi dan meningkat pada obesitas, sedangkan lemak cokelat menghasilkan panas (termogenesis) dan kemudian meningkatkan konsumsi energi. Oleh karena itu, lemak cokelat dan induksi sifat seperti lemak cokelat pada lemak putih, telah dipertimbangkan sebagai target dalam melawan obesitas. Tujuan penelitian ini adalah untuk mengetahui proses pencoklatan jaringan adiposa putih. Metode penelitian yang digunakan adalah metode penelusuran ilmiah. Hasil penelitian diperoleh bahwa adiposit krem merupakan adiposit cokelat yang muncul pada sel prekursor dari jaringan adiposa putih karena adanya stimuli. Adiposit krem sama seperti adiposit cokelat dilengkapi dengan mitokondria yang mengandung uncoupling protein 1 (UCP1), yang ketika teraktivasi akan mengendalikan sintesis ATP dan menstimulasi aktivitas rantai respirasi. Beberapa regulator seperti PPAR $\gamma$, PGC-1 $\alpha$, dan PRDM16 muncul sebagai pelaku utama dalam proses diferensiasi adiposit krem.
\end{abstract}

Kata kunci: Adiposit cokelat, Adiposit krem, Pencokelatan Jaringan Adiposa, UCP1

\section{PENDAHULUAN}

Obesitas merupakan keadaan yang umum, serius, dan merugikan (CDC, 2016). Keadaan ini di seluruh dunia telah bertambah lebih dari dua kali lipat sejak tahun 1980. Pada tahun 2014, lebih dari 1,9 milyar orang dewasa mengalami kelebihan berat badan (WHO, 2016). Obesitas berasosiasi dengan banyak penyakit seperti diabetes tipe 2 , resistensi insulin, dislipidemia, hipertensi, penyakit jantung, sleep apnea, dan beberapa tipe kanker, sehingga peningkatan obesitas telah menjadi masalah kesehatan utama (Kim \& Plutzky, 2016).

Obesitas disebabkan oleh ketidakseimbangan antara energi yang masuk dan konsumsi energi (Kim dkk, 2016). Jaringan adiposa dalam tubuh ada dua tipe yang fungsinya berbeda, yakni jaringan adiposa putih dan jaringan adiposa cokelat (Esteve, 2014). Berlawanan dengan lemak putih, yang utama dalam menyimpan energi dan meningkat pada obesitas, lemak cokelat menghasilkan panas (termogenesis) dan kemudian meningkatkan konsumsi energi. Oleh karena itu, lemak cokelat dan induksi sifat seperti lemak cokelat pada lemak putih, telah dipertimbangkan sebagai target dalam melawan obesitas. Lemak cokelat merupakan tempat penyimpanan terspesialisasi yang dapat meningkatkan pengeluaran energi dan memproduksi 
panas. Setelah beberapa penemuan terbaru mengenai lemak cokelat aktif pada manusia dan faktor transkripsi yang mempengaruhi diferensiasi adiposit cokelat, penelitian mengenai lemak cokelat telah menarik banyak perhatian dan terus berkembang (Kim \& Plutzky, 2016).

Adiposit cokelat pada jaringan adiposa cokelat dilengkapi dengan mitokondria yang mengandung uncoupling protein 1 (UCP1). UCP1 ketika teraktivasi akan mengendalikan sintesis ATP dan menstimulasi aktivitas rantai respirasi. Panas yang dihasilkan akan didistribusikan ke seluruh tubuh melalui sirkulasi. Adiposit krem juga mengekspresikan UCP1 dengan kapasitas termogenik pada jaringan adiposa putih sebagai respon terhadap berbagai stimuli (Giralt \& Villaroya, 2012). Proses pencokelatan jaringan adiposa dikendalikan oleh faktor seperti olahraga (Kim dkk, 2016).

\section{METODE}

Pembahasan melakukan penulusuran artikel terkait peran UCP1 dalam proses pencokelatan jaringan adiposa.

\section{HASIL DAN PEMBAHASAN}

\section{Tipe Jaringan Adiposa}

Jaringan adiposa putih merupakan jaringan penyimpan energi utama dalam tubuh dan juga berfungsi sebagai isolasi serta memberikan perlindungan mekanik beberapa organ vital. Adiposit dewasa dalam jaringan adiposa putih berfungsi sintesis triasilgliserol, penyerapan glukosa, dan lipogenesis (Esteve, 2014). Adiposit putih memiliki droplet lemak unilocular, mitokondria relatif sedikit, dan secara utama menyimpan lemak (Kim \& Plutzky, 2016). Jaringan ini yang memastikan bahwa ketika suplai energi pada tubuh berlebih dan/atau pengeluaran energi berkurang, kelebihan energi secara efisien disimpan di jaringan adiposa putih sebagai triasilgliserol (Esteve, 2014).

Sedangkan jaringan adiposa cokelat memiliki fungsi dalam memetabolisme asam lemak untuk memproduksi panas. Jaringan adiposa cokelat merupakan tempat produksi panas (termogenesis) yang utama pada mamalia. Pada manusia, jaringan adiposa cokelat ditemukan pada fetus dan bayi baru lahir di bagian aksilar, servikal, perirenal, dan periadrenal. Jaringan ini akan semakin sedikit keberadaannya setelah lahir dan pada orang dewasa (Esteve, 2014). Adiposit cokelat memiliki diameter yang lebih kecil daripada adiposit di jaringan adiposa putih. Selain itu, sel ini memiliki beberapa droplet lipid multilocular, sitoplasma yang relatif berlimpah, inti yang bulat, dan banyak mitokondria yang mengeluarkan panas dengan cara oksidasi asam lemak (Kim \& Plutzky, 2016). Mitokondria pada adiposit cokelat memiliki uncoupling protein-1 (UCP1). Ketika teraktivasi, sirkuit pendek gradient elektrokimia yang mengendalikan sinstesis ATP kemudian akan menstimulasi aktivitas rantai respirasi (Harms \& Seale, 2012; Coelho dkk, 2012)

Gambar 1. Gambaran perbedaan jaringan adiposa putih, jaringan adiposa krem, dan jaringan adiposa cokelat (Wakhande dkk, 2016)

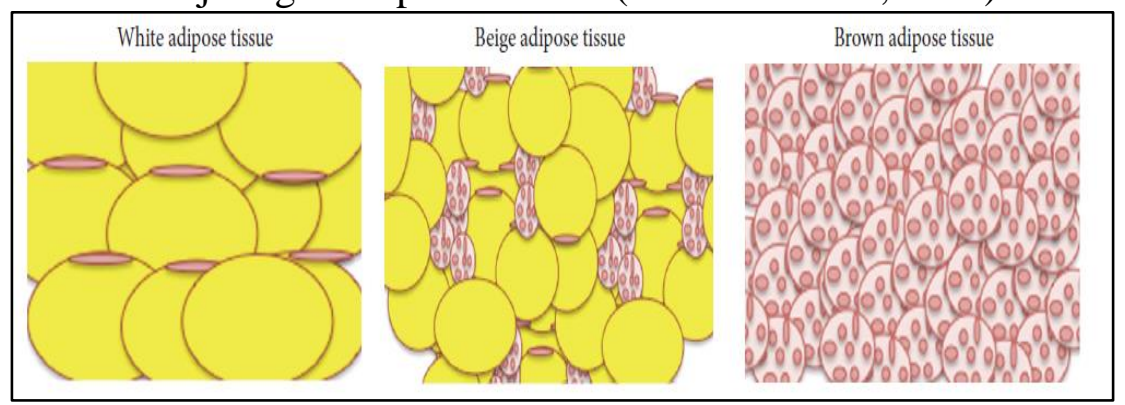




\section{Uncoupling Protein 1 (UCP1)}

UCP1 atau sering juga disebut termogenin atau SLC25A7, merupakan protein dimer 33-kDa yang mengurangi gradient $\mathrm{pH}$ yang dihasilkan oleh fosforilasi oksidatif, menghasilkan energi sebagai panas (Brondani dkk, 2012). Protein ini merupakan fitur yang jelas adiposit cokelat dan bertanggungjawab untuk kemampuan termogenesis di jaringan adiposa cokelat. Protein tersebut mengkatalis kebocoran proton disepanjang membran dalam mitokondria, menghilangkan gradient proton elektrokimia, yang jika tidak, akan mengendalikan produksi ATP oleh sintase ATP. Hasilnya adalah energi dari oksidasi substrat respirasi keluar sebagai panas. Oleh karena itu, oksidasi substrat dilepas dari fosforilasi ADP. Manusia memiliki adiposit cokelat klasik dan adiposit krem, bentuk yang direkrut dari jaringan adiposa putih. Jaringan ini menggunakan UCP1 dan ketika teraktivasi (contoh: oleh pajanan dingin), memiliki potensial untuk berkontribusi dalam pengeluaran energi seluruh tubuh (Crichton, 2017).

Gambar 2. Aktivasi UCP1 (Harms \& Seale, 2012)

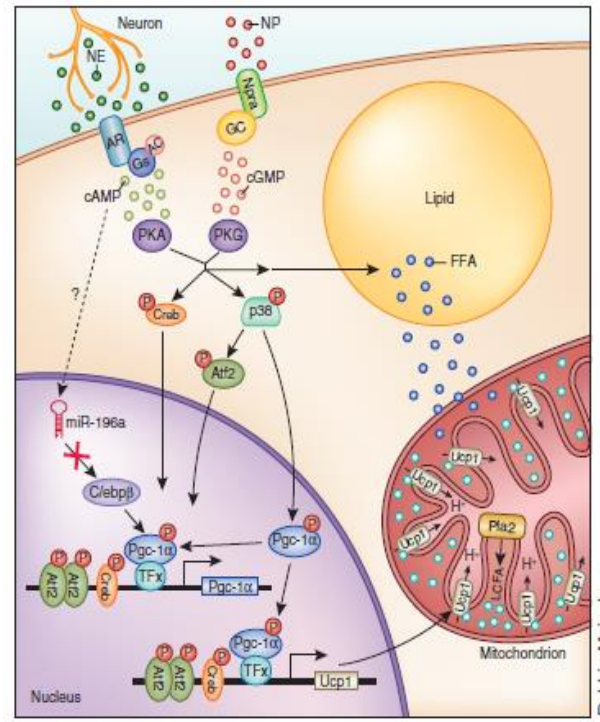

\section{Proses Pencokelatan Pada Jaringan Adiposa}

Pada tahun-tahun terbaru, peneliti telah mencari untuk menetapkan molekul intraselular dan ekstraselular yang memerintah diferensiasi setiap tipe prekursor untuk menjadi adiposit cokelat klasik atau adiposit krem. Beberapa regulator seperti PPAR $\gamma$, PGC-1 $\alpha$, dan PRDM16 muncul sebagai pelaku utama dalam proses diferensiasi. Beberapa kelompok mengklaim bahwa proses pencokelatan muncul melalui transdiferensiasi adiposit putih menjadi adiposit krem. Adiposit "paucilocular" (positif UCP1 dengan distribusi droplet lipid tengah-tengah antara adiposit cokelat dan putih) telah dilaporkan dan dianggap menunjukkan bentuk tengah-tengah adiposit yang berubah dari adiposit putih menjadi adiposit krem. (Giralt \& Villaroya, 2012). Proses diferensiasi adiposit cokelat diilustrasikan pada gambar 3.

PPAR $\gamma$ merupakan faktor transkripsi yang penting dalam diferensiasi adiposit cokelat dan putih. Selain itu, PPAR $\gamma$ berpartisipasi dalam aktivasi gen adiposit cokelat yakni UCP1 Aktivasi PPAR $\gamma$ menginduksi sel seperti adiposit cokelat pada preadiposit putih yang berdiferensiasi menjadi adiposit dewasa, membuat sel tersebut sekitar $10 \%$ nya menjadi positif UCP 1 (Seale, 2015). Sel seperti adiposit cokelat atau disebut adiposit krem tersebut tidak hanya ekspresi UCP1 saja yang meningkat, tetapi juga ekspresi PGC-1 $\alpha$ (peroxisome proliferatoractivated receptor $\gamma$ coactivator $1 \alpha$ ) dan gen-gen yang terlibat dalam biogenesis mitokondria. Adiposit krem ini juga berbeda dengan adiposit cokelat klasik karena adiposit krem tidak mengekspresikan faktor transkripsi spesifik jaringan adiposa cokelat. PPAR $\gamma$ dibutuhkan untuk rekrutmen PRDM 16 ke kompleks transkripsi PPAR $\gamma$, yang akan membuat proses pencokelatan. Proses pencokelatan tidak hanya melibatkan induksi gen spesifik adiposit 


\section{Indonesian Journal of Health Science}

\section{Volume 1 No. 2, Desember 2021}

cokelat, tetapi juga menekan gen adiposit putih. PPAR $\gamma$ bersamaan dengan C/EBP $\alpha$ (CCAAT/enhancer-binding protein $\alpha$ ) and CtBP (C-terminalbinding protein) 1 dan 2 menekan gen adiposit putih (Lo \& Sun, 2012)

PGC-1 $\alpha$ atau Coactivator $1 \alpha$ merupakan koaktivator transkripsi yang terlibat dalam mengontrol metabolisme energi yang banyak diekspresikan di jaringan adiposa cokelat. PGC$1 \alpha$ meningkat ekspresinya ketika ada pajanan dingin (Lo \& Sun, 2012) Ekspresi PGC-1 $\alpha$ pada adiposit putih membuat munculnya karakteristik adiposit cokelat, seperti ekspresi UCP 1 dan meningkatnya mitokondria. Pada adiposit cokelat, PGC-1 $\alpha$ mengendalikan aktivasi gen termogenik sebagai respon terhadap dingin. PGC-1 $\alpha$ difosforilasi dan diaktifkan oleh protein kinase teraktivasi mitogen p38, kemudian PGC-1 $\alpha$ akan berikatan dengan berbagai faktor transkripsi untuk menginduksi ekspresi gen termogenik seperti UCP 1 (Seale, 2015).

PRDM 16 atau PR domain containing 16 merupakan faktor penentu dalam perkembangan adiposit cokelat, faktor ini diperlukan dalam adipogenesis adiposit cokelat pada jaringan adiposa putih. PRDM 16 berikatan dan meningkatkan fungsional transkripsi PPAR $\gamma$, PGC-1 $\alpha$, dan cEBP. PRDM 16 berikatan dengan kromatin pada gen adiposit cokelat dan menstimulasi transkripsi melalui MED 1 (kompleks mediator) untuk meningkatkan fungsi transkripsi PPAR $\gamma$ untuk mengaktifkan transkripsi UCP1. PRDM 16 juga dibutuhkan dalam menekan ekspresi gen adiposit putih dengan merekrut kompleks CtBP 1 dan 2 (Lo \& Sun, 2012). Gambaran mengenai pengaruh regulator PPAR $\gamma$, PGC-1 $\alpha$, dan PRDM 16 terdapat pada gambar 5 .

Gambar 3. Efek tiga regulator transkripsi inti yang menginduksi lemak cokelat yakni PPAR $\gamma$, PGC-1 $\alpha$, dan PRDM 16 (Kim \& Plutzky, 2016)

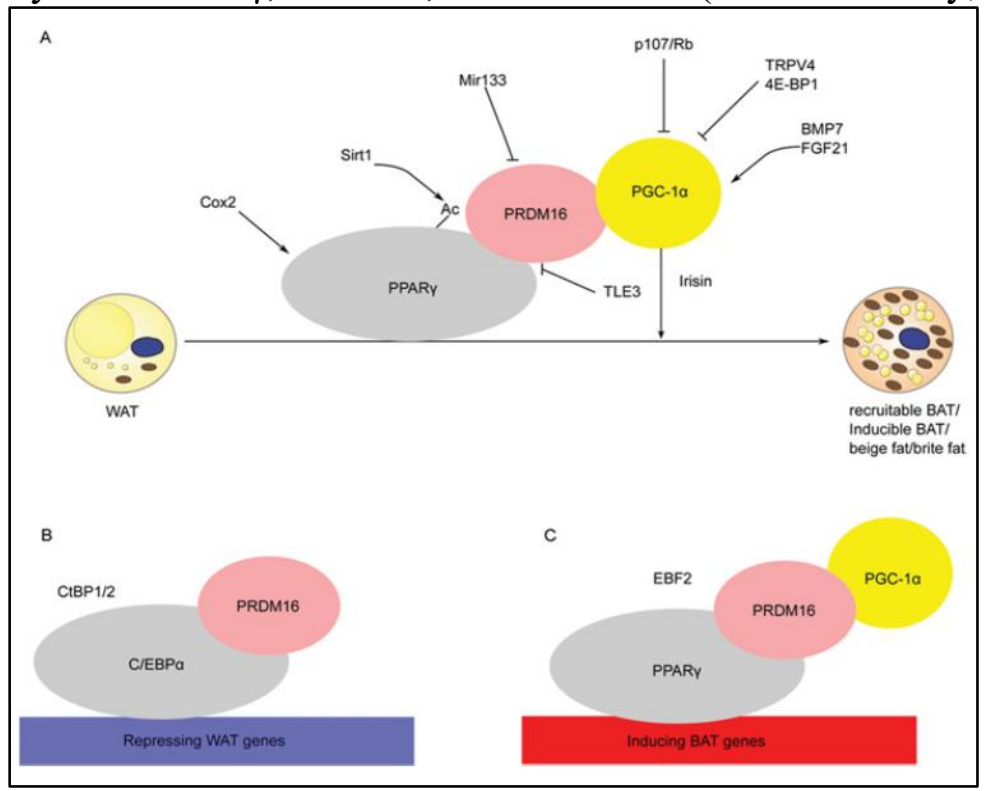

\section{PENUTUP}

Obesitas disebabkan oleh ketidakseimbangan antara energi yang masuk dan konsumsi energi. Jaringan adiposa dalam tubuh ada dua tipe yang fungsinya berbeda, yakni jaringan adiposa putih dan jaringan adiposa cokelat. Berbeda dengan jaringan adiposa putih, jaringan adiposa cokelat menghasilkan panas (termogenesis) sehingga dapat meningkatkan konsumsi energi. Oleh karena itu, lemak cokelat dan induksi sifat seperti lemak cokelat pada lemak putih, telah dipertimbangkan sebagai target dalam melawan obesitas. Adiposit krem dapat muncul setelah stimulasi termogenik pada jaringan adiposa putih. Proses tersebut adalah pencokelatan jaringan adiposa putih. Proses pencokelatan jaringan adiposa dikendalikan oleh faktor seperti olahraga. 


\section{DAFTAR PUSTAKA}

CDC. (2016, September 1). Adult Obesity Facts. Diakses 22 Februari 2017, dari https://www.cdc.gov/obesity/data/adult.html..

WHO. (Juni 2016). Obesity and overweight. Diakses 22 Februari 2017, dari http://www.who.int/mediacentre/factsheets/fs311/en/.

Kim, S.H. \& Plutzky, J. (2016). Brown Fat and Browning for the Treatment of Obesity and Related Metabolic Disorders. Diabetes Metab J, 40(1):1-12.

Esteve R, M. (2014) Adipose tissue: Cell heterogeneity and functional diversity. Endocrinol y Nut,61(2):100-12.

Giralt M \& Villarroya F. (2012). White, brown, beige/brite: Different adipose cells for different functions? Endocrinology, 154(9):2992-3000.

Harms M. \& Seale P. (2012). Brown and beige fat: development, function and therapeutic potential. Nat Med,19(10):1252-63.

Coelho M., Oliveira T., \& Fernandes R. (2012). State of the art paper Biochemistry of adipose tissue : an endocrine organ.

Wankhade U.D, Shen M., Yadav H., Thakali K.M. (2016). Novel Browning Agents , Mechanisms , and Therapeutic Potentials of Brown Adipose Tissue.

NIH Public Access. (2008). ;86(12):3279-88.

Brondani L.D.A., Assmann T.S., Duarte G.C.K., Gross J.L., Canani L.H., \& Crispim D. (2012) The role of the uncoupling protein 1 (UCP1) on the development of obesity and type 2 diabetes mellitus. Arq Bras Endocrinol Metabol, 56(4):215-25.

Crichton P.G, Lee Y., \& Kunji E.R.S. (2017). The molecular features of uncoupling protein 1 support a conventional mitochondrial carrier-like mechanism. Biochimie, 124:35-50.

Seale P. (2015). Transcriptional Regulatory Circuits Controlling Brown Fat Development and Activation.64(2):2369-75.

Lo K.A, Sun L.( 2012). Turning WAT into BAT : a review on regulators controlling the browning of white adipocytes Bioscience Reports.711-20. 